\title{
Determinants of parasite species richness in Mediterranean marine fishes
}

\author{
Pierre Sasal $^{1, *}$, Serge Morand ${ }^{1}$, Jean-François Guégan ${ }^{2}$ \\ ${ }^{1}$ Laboratoire de Biologie Animale, UMR 5555 C.N.R.S., Université de Perpignan, avenue de Villeneuve, \\ F-66860 Perpignan Cedex, France \\ ${ }^{2}$ ORSTOM, 911 avenue Agropolis, BP 5045, F-34032 Montpellier Cedex 01, France
}

\begin{abstract}
Data on parasites of Mediterranean Sea fishes, collected from previous published surveys, were used to test 5 hypotheses concerning the determinants of parasite species richness. A total of 170 parasite species belonging to 5 distinct taxonomic groups (nematodes, acanthocephalans, digeneans, monogeneans and crustaceans) were identified from 79 marine fish species (3904 individuals) collected at a regional scale. Five independent variables concerning host life traits (body size, diet, range, abundance and schooling) were investigated and controlled for host sampling effort. A comparative analysis using the independent contrasts method was conducted in order to avoid phylogenetic confounding effects. We demonstrate the importance of taking host sampling effort into account when investigating the determinants of parasite species richness. Monogeneans were the only group for which the species richness showed a significant correlation with some of the varlables studied. Parasite species richness of monogeneans was positively correlated with host body size and negatively correlated with host species abundance. The positive relationship between fish body size and the number of parasite species on a regional scale may be explained by the hypothesis that larger host body size increases host vagility which in turn enhances exposure to more and more parasite species. Our findings disagree with previous studies that did not take either phylogenetic confounding effects or geographic scale into account. We demonstrate the importance of using phylogenetic information in comparative analyses by showing that fish body size was not correlated with geographical range when using phylogenetic independent contrasts. We also suggest that studying parasites of host species from the same geographical region avoids the problem of confounding various assembiages of hosts with distinct histories.
\end{abstract}

KEY WORDS: Parasite - Marine fish - Species richness - Independent contrasts Sampling effort - Body size Fish abundance

\section{INTRODUCTION}

Many ecologists (see for instance the forward-looking third edition of Begon et al. 1996) now recognize that parasitism and diseases are important factors affecting the viability of natural populations and communities (Dobson 1988, Scott 1988, Combes 1995, Morand \& Arias Gonzalez 1997). In the marine environment, it has been demonstrated that individual fish may suffer from parasitic attacks (Faliex \& Morand 1994), and Sasal et al. (1996) have shown the conspic-

·E-mail: digene@univ-perp.fr uous role of parasites on fish in marine reserves. However, it still remains to be explained why some fish species have a higher parasite species richness (i.e. the number of parasite species occurring in 1 host species) than others, and how parasite communities build up on these hosts.

The determinants of parasite richness of fish have been traditionally investigated in freshwater species (Bush et al. 1990, Bell \& Burt 1991, Guégan et al. 1992, Guégan \& Kennedy 1993, Aho \& Bush 1993), and it is obvious that parasite community ecology of freshwater fish has contributed considerably to the development of our general knowledge of parasite biodiversity (for marine examples see Campbell et al. 1980, Rohde 
1988, 1992, Holmes 1990, Rohde et al. 1995\}. All these investigations have focused on the characterization of the determinants of parasite richness such as host geographical range, host body size or host diet variables. However, none of these studies were controlled for the confounding effects exerted by common history on regressions, and host species were considered as independent statistical observations, now known to have the potential to bias statistics (Harvey \& Pagel 1991). For instance, Poulin (1995), using a phylogenetic comparison method, found that the richness of external parasites was not correlated with fish body size while a simple cross species comparison showed a positive relationship between species richness and host body size. Conversely, Guégan et al. (1992) have demonstrated host size to be the best predictor variable of richness of external parasites when using a non phylogenetic analysis, and Guégan \& Morand (1996) have confirmed these previous results when performing a phylogenetic comparison method on the same, but extended, data set.

The goal of this paper is to investigate the determinants of parasite species richness of Mediterranean Sea fishes. Five distinct, but non exclusive, hypotheses can be drawn within the context of parasite community ecology of fish. These can be formulated as follows:

(1) Parasite diversity (richness) is positively correlated with host body size because, in larger hosts, the available niches for parasite colonization are more diverse. This idea follows island biogeographic theory (MacArthur \& Wilson 1967) which predicts greater species richness on larger islands, with hosts considered here as islands (Kuris \& Blaustein 1977, Strong 1979, Tallamy 1983, Guégan et al. 1992). Larger hosts can also sustain a higher number of parasites, hence the time it takes for a species to go extinct in an individual host is reduced. Furthermore, larger fish have lived longer (as fishes grow during all their life), and therefore have a higher probability of encountering parasites during their life span than smaller and shorter-lived fish species.

(2) Parasite diversity is positively correlated with the proportion of fish in the diet because parasite species might accumulate along food chains. This could be particularly the case for endoparasites (Bell \& Burt 1991, Aho \& Bush 1993), but Guégan \& Kennedy (1993) have contradicted this view since top-predators do not accumulate parasites in a way comparable to bioaccumulation

(3) Parasite diversity is positively correlated with host range because a more widely distributed host will encounter more parasite species (Dritschilo et al. 1975, Price \& Clancy 1983, Gregory 1990).

(4) Parasite diversity is positively correlated with host abundance because hosts with larger populations will more readily sustain populations of adult parasites (Bell \& Burt 1991).

(5) Parasite diversity is correlated with host schooling because hosts forming shoals will facilitate transmission of their parasites (Gregory 1990, Holmes 1990 Côté \& Poulin 1995, see also Loehle 1995). This might be particularly true for directly transmitted parasites.

As Gregory (1990) and co-workers (Walther et al. 1995) pointed out, investigations on parasite species richness must take differential sampling effort into account. Differential sampling effort is a direct but independent consequence of both the researcher's sampling procedure and of the host geographical range: both variables may affect host-researcher encounters, and thus they directly influence the number of parasite species collected. However, Guégan \& Kennedy (1996) have proposed a different explanation for the intricate role of linked sampling effort and area variables on richness estimates. The high 3-way correlations observed among species richness, sampling effort and area may result from strong causal links among the 3 variables. If so, much of the contribution to richness made by sampling effort is also a contribution by area, and the total contribution of area logically incorporates a contribution from sampling effort. These findings suggest that a larger area may likely increase sampling effort directly, thus producing as a final result a larger total causal effect on richness (see Guégan \& Kennedy 1996 for further details).

The need to take phylogeny into account is related to the coevolution between hosts and their parasites Hence, host phylogeny may be important in determining the richness pattern of a parasite community (Holmes \& Price 1980, Brooks \& McLennan 1991). Also of interest are cross-species comparisons performed on species whose values, when considered as independent points, may be confounded by the phylogeny of species under analysis (Felsenstein 1985, Harvey \& Pagel 1991, Martins \& Garland 1991). For example, a significant correlation may arise between host body size and parasite species richness just because a group of related and same-sized host species have a high parasite richness due to their common phylogenetic origin and not because of common operating ecological forces. Thus, closely related species tend to be similar and species values cannot be treated as statistically independent points (Harvey \& Pagel 1991)

Here, we report for the first time on a phylogenetic analysis of the determinants of parasite species richness patterns in marine fishes for a well-defined biogeographical entity, the Adriatic Sea (northern Mediterranean Sea). The importance of explanatory variables as determinants of parasite species richness, and more specifically monogenean species richness, is considered in the light of new mathematical ap- 
proaches in evolutionary ecology. Finally, the findings are discussed with particular reference to the difficulties which arise when treating parasite data on a large scale.

\section{MATERIAL AND METHODS}

Data on hosts and parasites. Data on parasite species richness were compiled from published studies (Petter \& Radujkovic 1989, Radujkovic 1989, Radujkovic \& Euzet 1989, Radujkovic \& Raibaut 1989, Radujkovic et al. 1989, Trilles et al. 1989 and Appendix 1). The total number of parasite species collected from 79 marine fish species (3904 individuals) from the Adriatic Sea (considered to be the region) were recorded. A total of 170 parasite species belonging to 5 distinct taxonomic groups were identified. Monogeneans and crustaceans (copepods and isopods) were found on the external surfaces (gills, fins and body surface) of fishes whereas digeneans, nematodes and acanthocephalans were located in the gastro-intestinal tract. For each parasite group, systematic identification was carried out by the same person, avoiding taxonomic differences that may occur in multiple-person studies.

The total number of parasite species used here is taken to be the regional parasite species richness reported for each of the species under consideration. The measure of parasite species richness employed is based on a check-list of parasite species. As such, it combines data from the same geographical area and populations collected at different times. However, it represents a regional pool from which all component parasite communities are drawn (see Kennedy et al. 1986, Kennedy \& Guégan 1994 for a discussion). This measure of regional parasite species richness is informative in evaluating biogeographical patterns of richness (Aho \& Bush 1993), and in permitting direct comparisons between the influence of regional processes and local processes on richness (Kennedy \& Guégan 1994).

For each of the 79 fish species, the following information was taken into account:

(1) Host sample size. This represents the number of individuals examined for parasites per host species.

(2) Host body size. The adult maximal total body length was obtained from Whitehead et al. (1986).

(3) Host abundance. Host species were assigned a score ranging from 1 to 5 based on the occurrence in the Mediterranean Sea according to Whitehead et al. (1986)

(4) Host geographical range. The total surface area of the geographical range for each host species was calculated within the boundaries of the Mediterranean Sea, and then coded from 1 to 5 (1: presence in $20 \%$ of the Mediterranean Sea surface; 2: presence in $40 \%$; $3:$ presence in $60 \% ; 4$ : presence in $80 \% ; 5$ : presence in $100 \%$ ) according to Whitehead et al. (1986).

(5) Host diet. Information on host diet was obtained from Whitehead et al. (1986), and coded from 1 to 3 and scored as follows: 1, microphagous and planktophagous; 2 , omnivorous; 3 , carnivorous.

(6) Host schooling. Host species were assigned a score ranging from 0 to 2 ( 0 : isolated; 1 : small schooling; 2: large schooling) according to Whitehead et al. (1986).

Host phylogeny. Phylogeny of fish (Fig 1) was obtained from Lecointre (1994). Accurate estimates of branch length could not be obtained for the phylogeny of fish. Branch lengths were assumed to be equal.

Comparative analyses. The phylogenetic independent contrasts method (Felsenstein 1985, Martins \& Garland 1991, Garland et al. 1992, Pagel 1992) has been developed to resolve the problem of non-independence of data (i.e. traits measured across different species) in comparative studies. This method is now largely used in comparative analysis, and readers are invited to refer to the original references for further details on the methods (Garland et al. 1992). In the present study, we used the CAIC program for Macintosh (Purvis \& Rambaut 1995). Quantitative data are log transformed in order to stabilise variance (Harvey 1982). All correlations between contrasts were forced through the origin (Garland et al. 1992). In order to verify that contrasts were properly standardised we performed a regression of the absolute values of standardised contrasts versus their standard deviations (Garland et al. 1992).

Since parasite species richness and host range can correlate with sampling effort (Gregory 1990, Walther et al. 1995), both variables were first controlled for host sample size, and then only the richness variable was controlled for and the host range parameter kept untransformed as suggested by Guégan \& Kennedy (1996) before going ahead with regression techniques.

\section{RESULTS}

The distribution of parasite species richness (not corrected for host sample size) across host fish species was highly aggregated. Most fishes harbour a small number of parasite species whereas a few exhibit a large number of parasites (Fig. 2).

The regional parasite species richness was correlated with host sampling effort (Fig. 3a), thus demonstrating the importance of controlling for sampling artefacts before undertaking the comparative analyses. Additionally, there was a positive significant relationship between host species abundance and host sampling effort, which confirms the idea that host spe- 


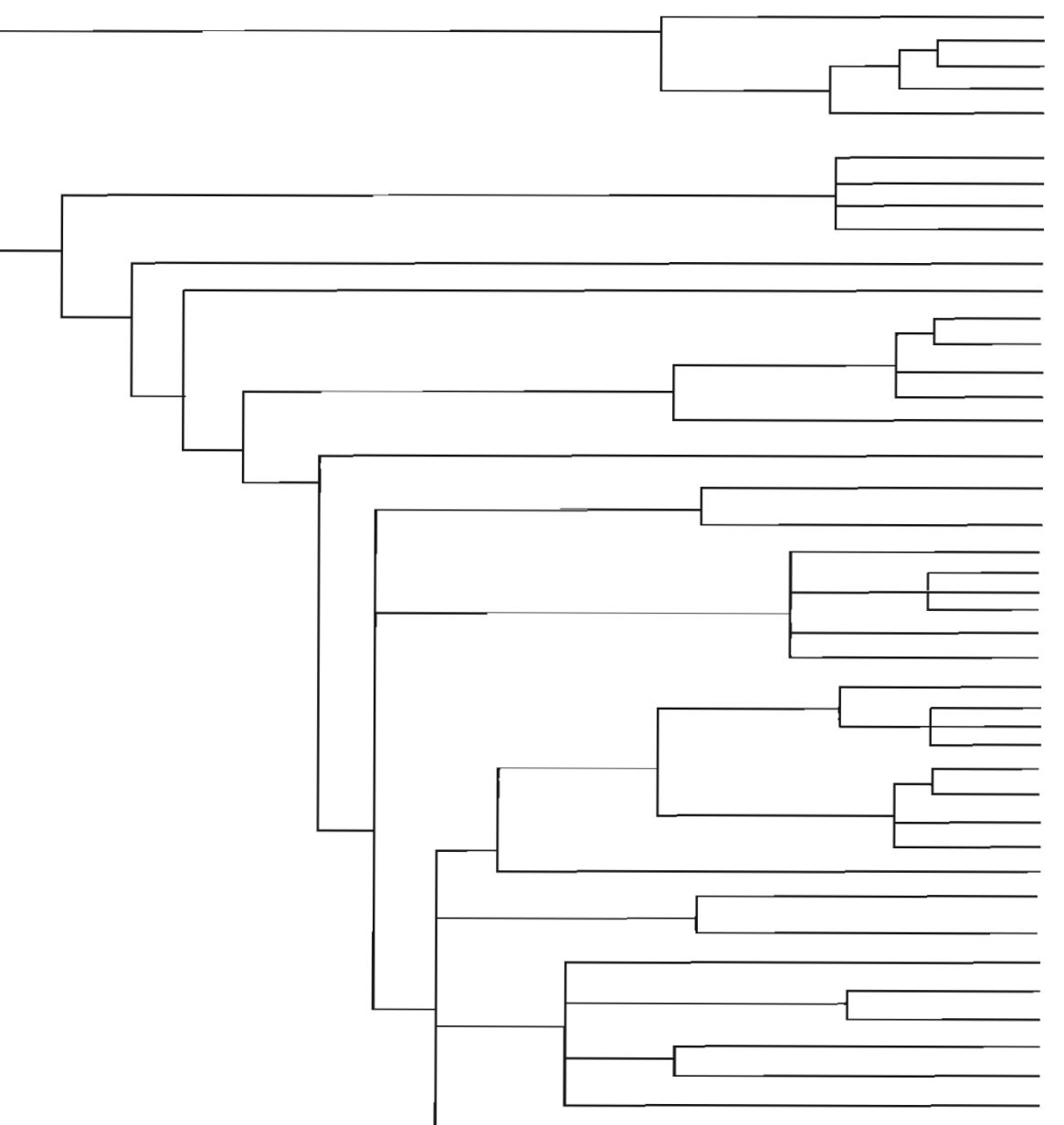

Scyliorhinus canicula Raja clavasa Raja miraletus Dasyatis pastinaca

Torpedo marmorata

Anguilla anguilla

Conger conger

Echilus myrus

Muraena helena

Sardina pilchardus

Chlorophtalmus agassizii

Phycis blennoides

P. phycis

Merluccius meriuccius

Trisoprerus minurus

Lophius budegassa

Zeus faber

Atherina boyeri

Belone belone

Chelon labrosus

Liza aurata

L. ramada

L. saliens

. Mugil cephalus

Oedalechelus labeo

Helicolenus dactylopteru.

Scorpaena notata

S. porcus
S. scrofa

Trigla lucerna

T. lyra

Lepidorrigla cavillone

Trigloporus latovitzat

Sphyraena sphyraena

Balistes carolinensis

Mola moia

Cisharus linguatula

Arnoglossus laterna

A. thori

Bublossidium luteum

Solea vulgaris

Phrynorhombus regius

Trachinus draco

Lesueurigobius friseii

Gobius bucchichii

G. cruentatus

G. niger

Labrus merula

Symphodus melops

S. ocellatus
S. finca

S. rostratus

S. cinereus

Uranoscopus scaber

Mullus barbatus

M. surmuletus

Trachurus mediterraneus

Spicara smaris

Chromis chromis

Sciaena umbra

U. cirrosa

Epinephelus marginatus

Serronus cabrillo

S. hepaus

S. scriba

Dicentrarchus tabrax

Dentex dentex

Pagellus acarne

P. eryhrinus

Lirhognatus mormyrus

Oblada melanura

Spondylosoma cantharus

Boops boops

Sparus aurota

Cepola rubescens

Diplodus amnularis

D. puntazzo

D. sargus

D. valgaris

analyses (based on Lecointre 1994) 


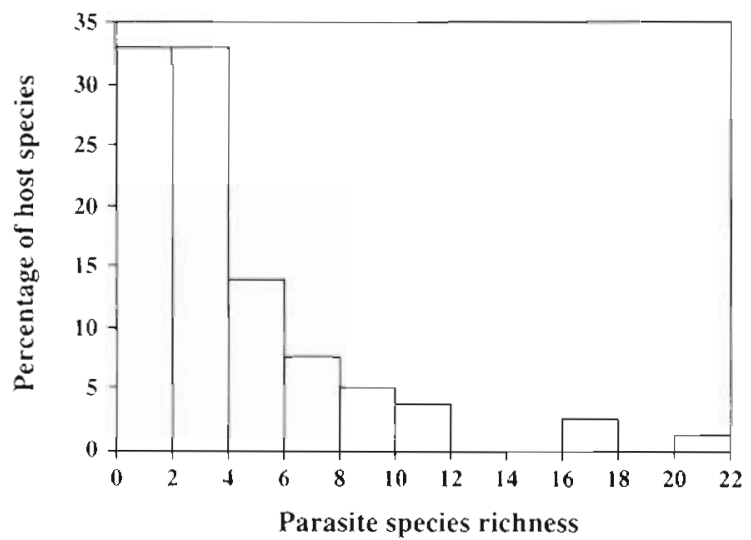

Number of parasite species / host species

Fig. 2. Frequency distribution of parasite species richness number of known parasite species per fish species; not corrected for host sample size)

cies with abundant populations are more easily sampled than hosts with lower or rarer populations (Fig. 3b).

Comparative analyses conducted on fish traits showed that fish species abundance was negatively correlated with fish species body size, which clearly means that larger fish species are also rare. The positive relationship between host species range and host species size, found when performing a conventional cross-species analysis, disappears when controlling for host phylogeny on regressions (Table 1).

A first set of comparative analyses was conducted on gastro-intestinal and external parasites separately, and then on all parasites (Tables $2 \& 3$ ). None of the independent variables were correlated with internal parasite species richness while all independent variables were correlated with external parasite species richness conly host body size was significantly correlated using Bonferroni correction). Both host size and host range variables were significantly correlated with the total regional parasite species richness (Table 2 ). When performing phylogenetic independent comparisons, only 1 positive correlation was found between host body size and external parasite richness, and the results
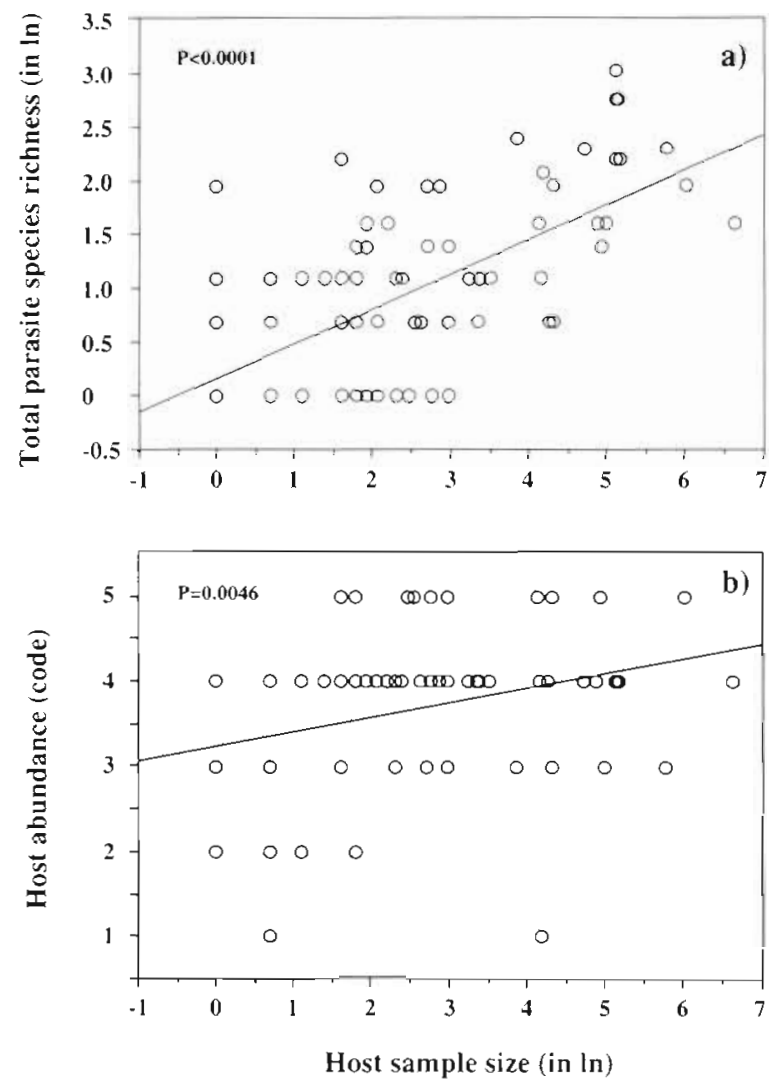

Fig. 3. Relationships between sampling effort (number of individual host sampled) and (a) total parasite richness ( $p<$ $0.0001)$ and (b) host abundance $(p=0.0046)$

observed for the total richness were unchanged (Table 3).

A second set of comparative analyses was conducted on the 4 different taxonomic groups of parasites represented in our data (Tables 4 \& 5). Results obtained with phylogenetic independent comparisons differed from those given with cross-species analyses. Conventional cross-species relationships show that: (1) monogenean species richness was correlated with all explanatory variables we tested except the host range variable (host size and diet were significantly correlated using Bonferroni correction); (2) crustacean and digenean

Table 1. Results of ordinary least-square regression performed both on cross-species and phylogenetically independent contrasts (through the origin) between host body length ( $\mathrm{n}(\mathrm{ln})$ and various dependent varlables. $\mathrm{p}$-values are indicated (estimated slope $b$ is given for significant $p \leq 0.05$ ); "significant relationships using a Bonferroni correction for multi-tests (here $p=0.05 / 4$ )

\begin{tabular}{|lcccc|}
\hline Host body size (in ln) & Abundance & Gregariousness & Diet & Host range \\
\hline Cross species & $\begin{array}{c}\mathbf{0 . 0 0 2 *} \\
(\mathbf{b}=-\mathbf{0 . 3 9 3 )}\end{array}$ & 0.617 & 0.326 & $\mathbf{0 . 0 0 2}$ \\
Phylogenetically independent contrasts & $\begin{array}{c}\mathbf{0 . 0 0 1 *} \\
(\mathbf{b}=-\mathbf{0 . 4 5 1 )}\end{array}$ & 0.064 & 0.928 & $\mathbf{. 0 . 3 2 4 )}$ \\
\end{tabular}


Table 2. Cross-species relationships between external, gastro-intestinal and total parasite species richness (controlled for host sampling effort) and various independent variables (all variables are controlled for sampling effort, except diet). $p$-values are indicated (estimated slope $b$ is given for significant $p \leq 0.05$ ); - significant relationships using a Bonferroni correction for multi-tests (here $\mathrm{p}=0.05 / 5$ )

\begin{tabular}{|c|c|c|c|}
\hline $\begin{array}{l}\text { Independent } \\
\text { variable }\end{array}$ & $\begin{array}{l}\text { External } \\
\text { parasites }\end{array}$ & $\begin{array}{c}\text { Gastro-intestinal } \\
\text { parasites }\end{array}$ & $\begin{array}{c}\text { Total } \\
\text { parasites }\end{array}$ \\
\hline Host size (in $\ln$ ) & $\begin{array}{c}0.0007^{\circ} \\
(b=0.304)\end{array}$ & 0.260 & $\begin{array}{c}0.0143 \\
(b=0.143)\end{array}$ \\
\hline Abundance (code) & $\begin{array}{c}0.0273 \\
(b=-0.179)\end{array}$ & 0.371 & 0.135 \\
\hline Gregariousness (code) & $\begin{array}{c}0.0149 \\
(b=0.226)\end{array}$ & 0.546 & 0.223 \\
\hline Diet (code) & $\begin{array}{c}0.0421 \\
(b=0.172)\end{array}$ & 0.698 & 0.077 \\
\hline Range (code) & $\begin{array}{c}0.0279 \\
(b=0.195)\end{array}$ & 0.696 & $\begin{array}{c}0.047 \\
(b=0.137)\end{array}$ \\
\hline
\end{tabular}

Table 3. Results of ordinary least-square regression (through the origin) performed on phylogenetically independent contrasts between external, gastrointestinal and total parasite species richness (controlled for host sampling effort) and various independent variables (all variables are controlled for sampling effort, except diet). p-values are indicated (the estimated slope $b$ is given for significant $\mathrm{p} \leq 0.05)_{i}$ " significant relationshups using a Bonferroni correction for multi-tests (here $p=0.05 / 5$ )

\begin{tabular}{|c|c|c|c|}
\hline $\begin{array}{l}\text { Independent } \\
\text { variable }\end{array}$ & $\begin{array}{l}\text { External } \\
\text { parasites }\end{array}$ & $\begin{array}{c}\text { Gastro-intestinal } \\
\text { parasites }\end{array}$ & $\begin{array}{c}\text { Total } \\
\text { parasites }\end{array}$ \\
\hline Host size (in In) & $\begin{array}{c}0.0005^{\circ} \\
(b=0.287)\end{array}$ & 0.869 & $\begin{array}{c}0.010^{\circ} \\
(b=0.221)\end{array}$ \\
\hline Abundance (code) & 0.09 & 0.502 & 0.279 \\
\hline Gregariousness (code) & 0.921 & 0.131 & 0.140 \\
\hline Diet (code) & 0.056 & 0.732 & 0.329 \\
\hline Range (code) & 0.273 & 0.431 & 0.055 \\
\hline
\end{tabular}

Table 4. Cross-species relationships between different taxonomical parasite species richness (controlled for host sampling effort) and various independent variables (all variables are controlled for sampling effort, except diet). p-values are indicated (the estimated slope $b$ is given for significant $\mathrm{p} \leq 0.05$ ); " significant

relationships using a Bonferroni correction for multi-tests (here $p=0.05 / 5$ )

\begin{tabular}{|c|c|c|c|c|}
\hline $\begin{array}{l}\text { Independent } \\
\text { variable }\end{array}$ & $\begin{array}{l}\text { Mono- } \\
\text { geneans }\end{array}$ & Crustaceans & Digeneans & Nematodes \\
\hline Host size (in ln) & $\begin{array}{c}0.002^{\circ} \\
(b=0.266)\end{array}$ & 0.072 & 0.611 & 0.298 \\
\hline Abundance (code) & $\begin{array}{c}0.018 \\
(b=-0.185)\end{array}$ & 0.313 & 0.951 & 0.473 \\
\hline Gregariousness (code) & $\begin{array}{c}0.044 \\
(b=0.280)\end{array}$ & $\begin{array}{c}0.0177 \\
(b=0.167)\end{array}$ & $\begin{array}{c}0.048 \\
(b=0.119)\end{array}$ & 0.096 \\
\hline Diet (code) & $\begin{array}{c}0.002^{\circ} \\
(b=0.247)\end{array}$ & 0.888 & 0.545 & 0.706 \\
\hline Range (code) & 0.121 & 0.128 & 0.318 & 0.721 \\
\hline
\end{tabular}

species richnesses were only affected by host species schooling; (3) nematode richness was affected by none of the independent variables analysed (Table 4). The effect of host species gregariousness on the different taxonomic group richness was withdrawn when controlling for the effect of host phylogeny, and only the host species size variable (Fig. 4a), the abundance variable (Fig. 4 b) and the diet variable were significant for explaining monogenean species richness (host size and diet were significantly correlated using Bonferroni correction) (Table 5). Fig. 4 a illustrates the positive relationship between independent contrasts of monogenean species richness and independent contrasts of host species body size, and Fig. 4 b shows the negative relationship between independent contrasts of monogenean species richness and independent contrasts of host species abundance.

\section{DISCUSSION}

None of the independent variables were correlated with internal parasite species richness while all independent variables were surprisingly correlated with external species richness.

The use of phylogenetic information in comparative analyses is important in order to avoid confounding effects between variables analyzed and phylogeny (Harvey \& Pagel 1991). However, ecologists are not all mindful of possible biases that may appear when comparing species without looking first at their genealogical links (Harvey 1996). For instance, in this study on the determinants of parasite species richness in different marine fish species of the Mediterranean Sea, we demonstrate that the host body size of a given fish species is not correlated with its geographical range when using phylogenetic independent contrasts. This result strongly contradicts the conventional non phylogenetic procedure, i.e. the use of species traits as independent variables, which remains a rather common view in ecol- 


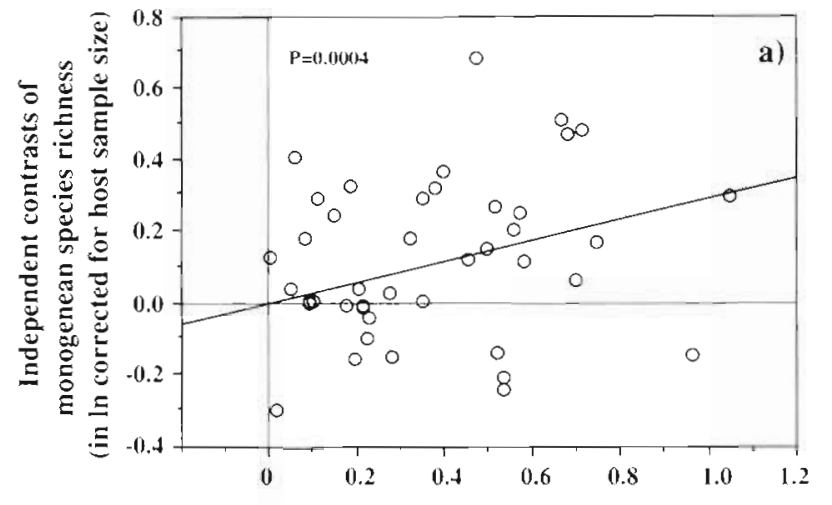

Independent contrasts of host body size (in In corrected for host sample size)

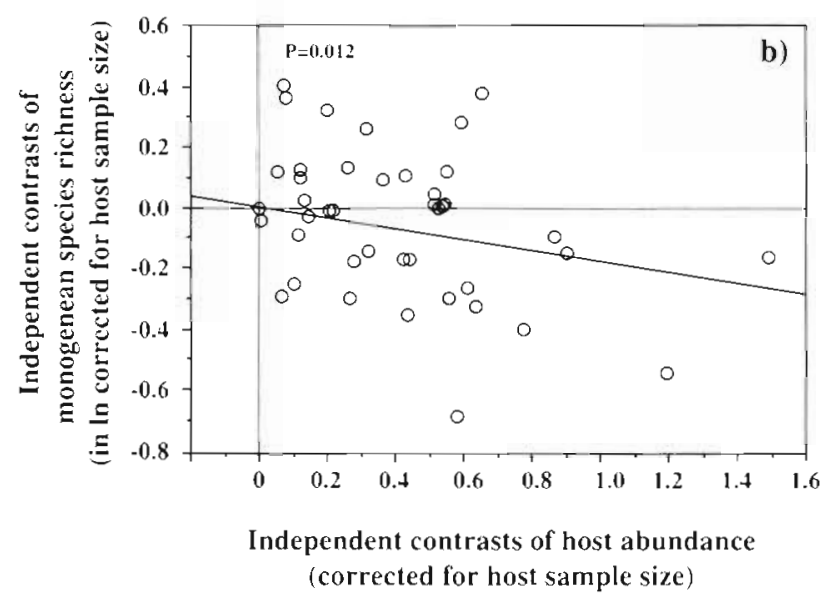

Fig. 4. Relationships between independent contrasts of monogenean species richness (corrected for host sample size) and (a) fish body size (in In) and (b) host abundance (in code, corrected for host sample size) ogy. We postulate that 2 fish species with the same body size tend to have geographical ranges equal in size (in terms of dimensional values but not necessarily in terms of common occupancies!) not only because larger sizes allow fish to occupy larger geographical ranges but also because closely related fish species tend to have similar body size, and thus similar range dimensions.

Walther et al. (1995) emphasized that both sampling effort and phylogeny must be controlled when investigating parasite species richness. Hence, a working phylogeny of marine fishes has been used and the independent contrasts method has been developed (Purvis \& Rambaut 1995) which considers the confounding effect played by sampling effort. Five independent variables (host body size, host diet, host range, host abundance, host schooling) were tested as possible determinants of parasite species richness, and used to confront 5 hypotheses commonly used in parasite community ecology to explain richness patterns.

- Hypothesis 1: Parasite species richness increases with host species size. This first hypothesis is well-supported by the results we present here, which are in accordance with the investigations of Guegan et al. (1992) and Guégan \& Morand (1996), made on maximal infracommunity parasite richness, which showed a positive relationship between host size and external parasite richness across different African cyprinid fish species. Our findings contrast with those of Poulin (1995), who found no correlation between external parasite richness and host size. A general positive relationship between host species size and the number of parasite species on a regional scale is not easy to explain since a single host of a given species does not generally harbour all the parasites present on a broader scale, but we think that larger host body size increases host vagility (and therefore makes them a better target for the infective stage of a parasite) which in turn enhances exposure to more and more parasite species on a regional scale (present study), and additionally hosts may sample the habitats more efficiently (Price 1990). Thus, larger sizes reached by host individuals of larger host species lead to higher total regional parasite richness. At this time, we suggest that by studying parasites of host species from the same geographical region with more or less definite boundaries we might avoid the problem of confounding various assemblages of hosts with distinct histories.

- Hypothesis 2: Parasite species richness accumulates in top-preda- 
tors. This hypothesis is not confirmed by our study on gastro-intestinal parasites of marine fishes, supporting the findings of Guégan \& Kennedy (1993) on internal parasites of British freshwater fishes. We can postulate that the accumulation of gastro-intestinal parasites along food chains will be more quantitative than qualitative, Large fish could eat more food but will not increase the diversity of potential intermediate hosts. However, a significant still unexplained correlation has been observed between the proportion of fish in the diet and the ectoparasite monogenean richness.

Hypothesis 3: Parasite species richness increases with host species range. This hypothesis is rejected due to the confounding effects of host body size and host geographical range. A non phylogenetic analysis would have concluded a positive host range-parasite richness relationship while a phylogenetic method shows that parasite species richness is not correlated with geographical range for Mediterranean marine fishes when a correction for phylogeny has been applied.

Hypothesis 4: Parasite species richness increases with host species abundance in the community. In contrast, we observe the inverse situation; the parasite species diversity of monogeneans is negatively correlated with host species abundance. This negative relationship could be intuitively explained by the negative correlation which has been observed between host species size and host abundance, since a larger host species can harbour a more diversified parasite community, and this larger host species is also less abundant in the community. Consequently, this fourth hypothesis is not valid and it cannot account for the observed pattern of parasite richness.

- Hypothesis 5: Parasite species richness increases with host gregariousness. This fifth and last hypothesis is not supported by our data when controlling for the effect of host phylogeny on regressions.
In summary, host species body size and host species abundance are the main determinants of ectoparasitic monogenean species richness across 79 marine fish species of the Mediterranean Sea. Host size accounts for $27 \%$ of the variance in monogenean species richness and this result can be compared to that obtained by Guégan \& Morand (1996) for freshwater fish in which host size explained $24 \%$ of the variance in parasite richness when controlling for the effect of phylogeny on regressions. Unfortunately, results concerning other taxonomic groups of parasites were not as conclusive as for monogeneans. Possibly, larger hosts may offer more spaces for parasite species and they are supposed to have a greater life expectancy for colonisation by sustainable parasite infrapopulations. Guégan \& Hugueny (1994) have demonstrated that host body size explained the monogenean infracommunity parasite species richness across different individual hosts of the same West African cyprinid fish species. Their analysis demonstrated that larger host individuals harboured more parasite species than smaller hosts. Since larger hosts are also less abundant in the population than smaller ones, this could explain why monogenean species richness is negatively correlated with host species abundance in our analysis. Finally, the results we give above differ from those of Poulin (1995) and Bush et al. (1990) in that the essential characteristic of our study is to deal with a unit geographical system, i.e. the Adriatic part of the Mediterranean Sea and its fauna, with well-defined boundaries, and not with 2 collections of hosts and their parasites caught all over the world. We conclude that it is absolutely necessary to investigate the diversity of parasites at the level of a definite geographical assemblage of hosts, such as the Mediterranean marine fishes we present in this work.

Appendix 1. Summary of data on host sample size, parasite species richness for each parasite group (Mono.: monogeneans; Crust.: crustaceans; Dig.: digeneans; Acan.: acanthocephalans; Nem.: nematodes), host abundance, size, range, gregariousness and diet for fish species included in the comparative analysis (see sources in 'Material and methods')

\begin{tabular}{|c|c|c|c|c|c|c|c|c|c|c|c|}
\hline Species & $\begin{array}{l}\text { Host } \\
\text { sample } \\
\text { size }\end{array}$ & Mono. & Crust. & Dig. & Acan. & Nem. & $\begin{array}{c}\text { Maximal } \\
\text { host size } \\
(\mathrm{cm})\end{array}$ & $\begin{array}{c}\text { Host } \\
\text { abundance } \\
\text { (code) }\end{array}$ & $\begin{array}{l}\text { Host } \\
\text { range } \\
\text { (code) }\end{array}$ & $\begin{array}{l}\text { Grega- } \\
\text { riousness } \\
\text { (code) }\end{array}$ & $\begin{array}{c}\text { Diet } \\
\text { (code) }\end{array}$ \\
\hline Anguilla angwhla & 72 & 0 & 1 & 1 & 0 & 0 & 150 & 4 & 5 & 0 & 2 \\
\hline Arnoglossus laterna & 8 & 0 & 0 & 2 & 0 & 5 & 20 & 4 & 5 & 0 & 2 \\
\hline Arnoglossus thon & 2 & 0 & 0 & 0 & 0 & 1 & 15 & 4 & 2 & 0 & 2 \\
\hline Atherina boyeri & 780 & 0 & 2 & 2 & 0 & 1 & 13 & 4 & 5 & 2 & 1 \\
\hline Balıstes carolnensis & 1 & 0 & 1 & 0 & 0 & 1 & 40 & 4 & 5 & 0 & 1 \\
\hline Belone belone & 6 & 1 & 0 & 0 & 0 & 0 & 60 & 2 & 4 & 2 & 3 \\
\hline Boops boops & 77 & 1 & 3 & 1 & 0 & 2 & 30 & 5 & 5 & 2 & 2 \\
\hline Buglossidium luteum & 1 & 0 & 1 & 0 & 0 & 0 & 13 & 3 & 5 & 0 & 1 \\
\hline Cepola rubescens & 13 & 0 & 1 & 0 & 0 & 1 & 30 & 5 & 5 & 1 & 1 \\
\hline Chelon labrosus & 169 & 4 & 6 & 3 & 1 & 2 & 60 & 4 & 5 & 2 & 2 \\
\hline Chlorophtalmus agassizu & 20 & 0 & 1 & 0 & 0 & 0 & 20 & 3 & 5 & 2 & 1 \\
\hline Chromis chromis & 16 & 0 & 0 & 0 & 0 & 1 & 12 & 5 & 5 & 1 & 1 \\
\hline
\end{tabular}


Appendix 1 (continued)

\begin{tabular}{|c|c|c|c|c|c|c|c|c|c|c|c|}
\hline Species & $\begin{array}{l}\text { Host } \\
\text { sample } \\
\text { size }\end{array}$ & Mono. & Crust. & Dig. & Acan & Nem. & $\begin{array}{l}\text { Maximal } \\
\text { host size } \\
(\mathrm{cm})\end{array}$ & $\begin{array}{l}\text { Host } \\
\text { abundance } \\
\text { (code) }\end{array}$ & $\begin{array}{l}\text { Host } \\
\text { range } \\
\text { (code) }\end{array}$ & $\begin{array}{l}\text { Grega- } \\
\text { rlousness } \\
\text { (code) }\end{array}$ & $\begin{array}{l}\text { Diet } \\
\text { (code) }\end{array}$ \\
\hline Citharus linguatula & 150 & 0 & 1 & 0 & 0 & 4 & 30 & 3 & 5 & 0 & 2 \\
\hline Conger conger & 6 & 0 & 1 & 1 & 0 & 2 & 250 & 4 & 5 & 0 & 3 \\
\hline Dasyatıs pastinaca & 29 & 2 & 0 & 0 & 0 & 0 & 250 & 4 & 5 & 0 & 3 \\
\hline Dentex dentex & 2 & 0 & 3 & 0 & 0 & 0 & 100 & 3 & 5 & 0 & 3 \\
\hline Dicentrarchus labrax & 6 & 1 & 1 & 0 & 0 & 0 & 100 & 4 & 5 & 1 & 3 \\
\hline Diplodus annularis & 173 & 9 & 5 & 6 & 0 & 1 & 18 & 4 & 5 & 1 & 1 \\
\hline Diplodus puntazzo & 5 & 6 & 3 & 0 & 0 & 0 & 45 & 3 & 5 & 1 & 2 \\
\hline Diplodus sargus & 176 & 11 & 3 & 1 & 0 & 1 & 40 & 4 & 5 & 2 & 3 \\
\hline Diplodus vulgans & 329 & 7 & 2 & 1 & 0 & 0 & 20 & 3 & 5 & 1 & 3 \\
\hline Echelus myrus & 1 & 0 & 0 & 1 & 0 & 2 & 80 & 2 & 5 & 1 & 3 \\
\hline Epmephelus marginatus & 2 & 2 & 0 & 0 & 0 & 0 & 140 & 1 & 5 & 0 & 3 \\
\hline Goblus bucchichii & 5 & 0 & 0 & 0 & 1 & 0 & 12 & 5 & 5 & 0 & 1 \\
\hline Coblus cruentatus & 6 & 0 & 0 & 0 & 1 & 0 & 18 & 4 & 3 & 0 & 1 \\
\hline Gobius niger & 143 & 0 & 1 & 1 & 1 & 1 & 15 & 5 & 5 & 0 & 1 \\
\hline Helicolenus dactylopterus & 10 & 1 & 0 & 0 & 0 & 2 & 45 & 3 & 5 & 0 & 2 \\
\hline Labrus merula & 5 & 0 & 1 & 0 & 0 & 0 & 45 & 3 & 5 & 1 & 2 \\
\hline Lepidotrigla cavillone & 10 & 0 & 0 & 0 & 0 & 1 & 20 & 4 & 5 & 1 & 1 \\
\hline Lesueurigabius friesu & 5 & 0 & 0 & 0 & 1 & 1 & 10 & 4 & 2 & 0 & 1 \\
\hline Lithognathus mormyrus & 15 & 3 & 1 & 3 & 0 & 0 & 50 & 3 & 5 & 2 & 3 \\
\hline Lizà aurala & 169 & 2 & 3 & 1 & 2 & 1 & 45 & 4 & 5 & 2 & 2 \\
\hline Liza ramada & 113 & 2 & 3 & 3 & 1 & 1 & 70 & 4 & 5 & 2 & 2 \\
\hline Liza saliens & 48 & 4 & 5 & 1 & 0 & 1 & 40 & 3 & 5 & 2 & 2 \\
\hline Lophrus budegassa & 3 & 0 & 1 & 0 & 0 & 0 & 80 & 2 & 5 & 0 & 3 \\
\hline Merlucclus merluccius & 67 & 1 & 4 & 0 & 0 & 3 & 135 & 1 & 5 & 1 & 3 \\
\hline Mola mola & 2 & 1 & 1 & 0 & 0 & 0 & 300 & 3 & 5 & 0 & 2 \\
\hline Mugil cephalus & 9 & 2 & 2 & 0 & 0 & 1 & 120 & 4 & 5 & 2 & 2 \\
\hline Mullus barbatus & 134 & 0 & 1 & 2 & 0 & 2 & 25 & 4 & 5 & 1 & 1 \\
\hline Mullus surmulletus & 10 & 0 & 0 & 0 & 0 & 1 & 40 & 3 & 5 & 1 & 1 \\
\hline Muraena helena & 1 & 0 & 1 & 0 & 0 & 0 & 150 & 4 & 5 & 0 & 3 \\
\hline Oblada melanura & 8 & 0 & 0 & 0 & 0 & 1 & 150 & 4 & 5 & 2 & 2 \\
\hline Oedalechilus labeo & 2 & 0 & 1 & 0 & 0 & 0 & 30 & 2 & 5 & 2 & 2 \\
\hline Pagellus acarne & 34 & 2 & 1 & 0 & 0 & 0 & 35 & 4 & 5 & 1 & 2 \\
\hline Pagellus erythrinus & 179 & 3 & 3 & 2 & 0 & 1 & 50 & 4 & 5 & 2 & 3 \\
\hline Phrynorhombus reguss & 2 & 0 & 0 & 0 & 0 & 1 & 15 & 3 & 2 & 0 & 3 \\
\hline Phycis bleanordes & 2 & 0 & 0 & 0 & 0 & 1 & 60 & 2 & 3 & 0 & 1 \\
\hline Phycas phycas & 2 & 0 & 0 & 0 & 0 & 1 & 50 & 2 & 3 & 0 & 3 \\
\hline Raja clavata & 11 & 1 & 1 & 0 & 0 & 1 & 110 & 4 & 5 & 0 & 3 \\
\hline Raja miraletus & 5 & 0 & 0 & 0 & 0 & 1 & 60 & 4 & 5 & 0 & 3 \\
\hline Sardina pilcharus & 77 & 0 & 1 & 0 & 0 & 1 & 25 & 3 & 4 & 2 & 1 \\
\hline Scraena umbra & 15 & 3 & 1 & 0 & 0 & 0 & 75 & 3 & 5 & 1 & 3 \\
\hline Scorpaena notatá & 12 & 0 & 0 & 0 & 0 & 1 & 20 & 5 & 5 & 0 & 3 \\
\hline Scorpaena porcus & 65 & 0 & 1 & 0 & 0 & 2 & 30 & 4 & 5 & 0 & 3 \\
\hline Scorpaena scrofa & 2 & 0 & 1 & 0 & 0 & 0 & 50 & 4 & 5 & 0 & 3 \\
\hline Scylorhinus canicula & 6 & 1 & 1 & 0 & 0 & 1 & 80 & 5 & 5 & 0 & 2 \\
\hline Serranus cabrilla & 30 & 1 & 0 & 1 & 0 & 1 & 35 & 4 & 5 & 0 & 3 \\
\hline Serranus hepatus & 26 & 0 & 1 & 0 & 0 & 2 & 14 & 4 & 5 & 0 & 3 \\
\hline Serranus scnba & 8 & 0 & 0 & 0 & 0 & 2 & 25 & 4 & 5 & 0 & 3 \\
\hline Solea vulgaris & 8 & 0 & 1 & 0 & 0 & 1 & 70 & 4 & 4 & 0 & 1 \\
\hline Sparus aurata & 5 & 2 & 0 & 1 & 0 & 0 & 70 & 4 & 5 & 1 & 3 \\
\hline Sphyraena sphyraena & 1 & 1 & 0 & 0 & 0 & 0 & 150 & 2 & 5 & 0 & 3 \\
\hline Spicara smans & 414 & 2 & 3 & 0 & 0 & 2 & 20 & 5 & 4 & 2 & 1 \\
\hline Spondylosoma cantharus & 1 & 0 & 1 & 0 & 0 & 0 & 50 & 4 & 5 & 2 & 2 \\
\hline Symphodus cinereus & 20 & 1 & 2 & 0 & 0 & 1 & 50 & 4 & 5 & 0 & 1 \\
\hline Symphodus melops & 1 & 0 & 1 & 0 & 0 & 0 & 25 & 4 & 2 & 1 & 1 \\
\hline Symphodus ocellatus & 20 & 0 & 1 & 0 & 0 & 1 & 12 & 5 & 5 & 0 & 1 \\
\hline Symphodus rostratus & 14 & 0 & 2 & 0 & 0 & 0 & 13 & 4 & 5 & 0 & 1 \\
\hline Symphodus tunca & 63 & 0 & 1 & 3 & 0 & 1 & 35 & 5 & 5 & 2 & 1 \\
\hline Torpedo marmorata & 16 & 1 & 0 & 0 & 0 & 0 & 100 & 4 & 5 & 0 & 3 \\
\hline Trachinus draco & 2 & 1 & 2 & 0 & 0 & 0 & 40 & 4 & 5 & 0 & 2 \\
\hline Trachurus mediterraneus & 18 & 2 & 1 & 2 & 0 & 2 & 50 & 4 & 5 & 2 & 2 \\
\hline Trigla lucerna & 3 & 1 & 2 & 0 & 0 & 0 & 75 & 4 & 5 & 0 & 1 \\
\hline Trigla lyra & 7 & 0 & 1 & 0 & 0 & 0 & 60 & 4 & 5 & 0 & 1 \\
\hline Trigloporus lastoviza & 4 & 1 & 0 & 0 & 0 & 2 & 40 & 4 & 5 & 0 & 1 \\
\hline Trisopterus minutus & 7 & 0 & 1 & 0 & 0 & 0 & 40 & 4 & 2 & 2 & 2 \\
\hline Umbrina cirrosa & 1 & 4 & 3 & 0 & 0 & 0 & 100 & 2 & 5 & 0 & 3 \\
\hline Uranoscopus scaber & 7 & 0 & 0 & 2 & 0 & 3 & 30 & 4 & 5 & 0 & 2 \\
\hline Zeus faber & 7 & 0 & 1 & 0 & 0 & 3 & 70 & 4 & 5 & 0 & 2 \\
\hline
\end{tabular}


Acknowledgements. This work was financially supported by the Conseil Régional du Languedoc Roussillon and the Programme National sur le Déterminisme du Recrutement (P.N.D.R.). Arnaud Teil helped with bibliographic work. The authors thank Michel Pichon and Gabriele Sorci for helpful comments on the first draft of this paper We are also very grateful to Claude Combes, David Marcogliese, Mike Moser, John Holmes and 3 anonymous referees for constructive suggestions and comments which greatly improved the final form of the manuscript.

\section{LITERATURE CITED}

Aho JM, Bush AO (1993) Community richness in parasites of some freshwater fishes from North America. In: Ricklefs RE, Schluter D (eds) Species diversity in ecological communities: historical and geographical perspectives. University of Chicago Press, Chicago, p 185-190

Begon M, Harper JL, Townsend CR (1996) Ecology. Individuals, populations and communities, 3rd edn. Blackwell Science, Oxford

Bell G, Burt A (1991) The comparative biology of parasite species diversity: intestinal helminths of freshwater fishes J Anim Ecol 60:1046-1063

Brooks DR, McLennan DA (1991) Phylogeny, ecology, and behavior. A research program in comparative biology. The University of Chicago Press, London

Bush AO, Aho JM, Kennedy CR (1990) Ecological versus phylogenetic determinants of helminth parasite community richness. Evol Ecol 4:1-20

Campbell RA, Haedrich RL, Munroe TA (1980) Parasitism and ecological relationships among deep-sea benthic fishes. Mar Biol 57:301-313

Combes C (1995) Interactions durables: écologie et évolution du parasitisme. Masson, Paris

Côté IM. Poulin R (1995) Parasitism and group size in social animals: a meta-analysis. Behav Ecol 6:159-165

Dobson AP (1988) Restoring island ecosystems: the potential. of parasites to control introduced mammals. Conserv Biol 2:31-39

Dritschilo W, Cornell H, Nafus D, O'Connor B (1975) Insular biogeography of mice and mites. Science 190:467-469

Faliex E, Morand S (1994) Population dynamics of the metacercarial stage of the bucephalid trematode, Labatrema minimus (Stossich, 1887) from Salses-Leucate lagoon (France) during the cercarial shedding period. J Helminthol 68:35-40

Felsenstein $J$ (1985) Phylogenies and the comparative method. Am Nat 125:1-15

Garland T Jr, Harvey PH, Ives AR (1992) Procedures for the analysis of comparative data using phylogenetically independent contrasts. Am Nat 41:18-32

Gregory RD (1990) Parasites and host geographic range as illustrated by waterfowl. Funct Ecol 4:645-654

Guégan JF, Hugueny B (1994) A nested parasite species subset pattern in tropical fish: host as major determinant of parasite infracommunity structure. Oecologia 100 $184-189$

Guégan JF, Kennedy CR (1993) Maximum local helminth parasite community richness in British freshwater fish: a test of the colonization time hypothesis. Parasitology 106: $61-100$

Guégan JF, Kennedy CR (1996) Parasite richness/sampling effort/host range: the fancy three-piece jigsaw puzzle. Parasitol Today 12:367-369

Guégan JF, Lambert A, Lévèque C, Combes C, Euzet L (1992)
Can host body size explain the parasite species richness in tropical freshwater fishes? Oecologia 90:197-204

Guégan JF, Morand S (1996) Polyploid hosts: strange attractors for parasites! Oikos 7:366-370

Harvey PH (1982) On rethinking allometry. J Theor Biol 95 $37-41$

Harvey PH (1996) Phylogenies for ecologists. J Anim Ecol 65 $255-263$

Harvey PH, Pagel M (1991) The comparative method in evolutionary biology. Oxford University Press, Oxford

Holmes JC (1990) Helminth communities in marine fishes. In Esch G, Bush A, Aho J (eds) Parasite communities: patterns and processes. Chapman and Hall, London, p $101-130$

Holmes JC, Price PW (1980) Parasite communities: the roles of phylogeny and ecology. Syst Zool 29:203-213

Kennedy CR, Bush AO, Aho JM (1986) Patterns in helminth communities: why are birds and fish different? Parasitology 93:205-215

Kennedy CR, Guégan JF (1994) Regional versus local helminth parasite richness in British freshwater fish: saturated or unsaturated parasite communities? Parasitology 109:175-185

Kuris AM, Blaustein AR (1977) Ectoparasitic mites on rodents application of the island biogeography theory? Science 195:596-598

Lecointre G (1994) Aspects historiques et heuristiques de l'ichtyologie systématique. Cybium 18:339-430

Loehle $C$ (1995) Social barriers to pathogen transmission in wild animal populations. Ecology 76:326-335

MacArthur RH, Wilson EO (1967) The theory of island biogeography. Princeton University Press, Princeton, NJ

Martins EP, Garland T Jr (1991) Phylogenetic analyses of the correlated evolution of continuous characters: a simulation study. Evolution 45:534-557

Morand S, Arias Gonzalez E (1997) Is parasitism a missing ingredient in model ecosystems? Ecol Model (in press)

Pagel MD (1992) A method for the analysis of comparative data. J Theor Biol 156:431-442

Petter AJ, Radujkovic BM (1989) Parasites des poissons marins du Monténégro: nématodes. Acta Adriat 30: $195-236$

Poulin R (1995) Phylogeny, ecology, and the richness of parasite communities in vertebrates. Ecol Monogr 65:283-302

Price PW (1990) Host populations as resources defining parasite community organization. In: Esch G, Bush A, Aho J (eds) Parasite communities: patterns and processes. Chapman and Hall, London, p 21-40

Price PW, Clancy KM (1983) Patterns in number of helminth parasite species in freshwater fishes. J Parasitol 69: $449-454$

Purvis A, Rambaut A (1995) Comparative analysis by independent contrasts (CAIC): an Apple Macintosh application for analysing comparative data. Comp Appl Biosci 11: 247-251

Radujkovic BM (1989) Parasites des poissons marins du Monténégro: acanthocéphales. Acta Adriat 30:189-194

Radujkovic BM, Euzet L (1989) Parasites des poissons marins du Monténégro: monogènes. Acta Adriat 30:51-135

Radujkovic BM, Orecchia P, Paggi L (1989) Parasites des poissons marins du Monténégro: digènes. Acta Adriat 30: 137-187

Radujkovic BM, Raibaut A (1989) Parasites des poissons marins du Monténégro: copépodes. Acta Adriat 30: $237-278$

Rohde K (1988) Gill Monogenea of deepwater and surface fish in southeastern Australia. Hydrobiologia 160:271-283 
Rohde K (1992) Latitudinal gradients in species diversity: the search for the primary cause. Oikos 65:514-527

Rohde K, Hayward C. Heap M (1995) Aspects of the ecology of metazoan ectoparasites of marine fishes. Int J Parasitol 25:945-970

Sasal P, Fallex E, Morand S (1996) Parasitism of Gobius bucchichii Steindachner, 1870 (Teleostei, Gobiidae) in protected and unprotected manne environment. J Wildl Dis 32:607-613

Scott ME (1988) The impact of infection and disease on animal populations: implications for conservation biology. Conserv Biol 2:40-56

Strong DR (1979) Biogeographic dynamıcs of insect-host plant

This article was submitted to the editor communities. Ann Rev Entomol 24:89-119

Tallamy DW (1983) Equilibrım biogeography and its application to insect host-parasite systems. Am Nat 121 $244-254$

Trilles JP, Radujkovic BM, Romestand B (1989) Parasites des poissons marins du Monténégro: isopodes. Acta Adriat 30 279-306

Walther BA, Clayton DH, Cotgreave PC, Gregory RD, Price RD (1995) Sampling effort and parasite species richness Parasitol Today 11:306-310

Whitehead PJP, Bauchot ML, Hureau JC, Nielsen J, Tortonese E (1986) Check-list of the fishes of the North-eastern Atlantic and of the Mediterranean. UNESCO, Paris

Manuscript first received: November 18, 1996

Revised version accepted: February 4, 1997 